\title{
ENVIRONMENTAL POLLUTION WITH OIL PRODUCTS AND REVIEW OF POSSIBILITIES FOR COLLECTION THEREOF
}

\author{
Juris Treijs ${ }^{1}$, Edmunds Teirumnieks $^{2}$, Viktors Mironovs ${ }^{3}$ \\ 1- Rezeknes Augstskola, Faculty of Engineering \\ Atbrivosanas aleja 76, LV 4601, Rezekne, Latvia; e-mail: juristreijs@inbox.lv \\ 2- Rezeknes Augstskola, Faculty of Engineering \\ Environment Technology Transfer Contactpoint \\ Atbrivosanas aleja 76, LV 4601, Rezekne, Latvia \\ $\mathrm{Ph} / \mathrm{fax}$ : 371 64625167, e-mail: edmunds@ru.lv \\ 3- Riga Technical University, Faculty of Civil Engineering \\ Department of Building Production \\ Azenes Street 16/20, Riga, LV 1048, Latvia; e-mail: viktors.mironovs@ gmail.com
}

\begin{abstract}
The largest global pollution nowadays gives oil and oil products. This contamination poses a danger to the environment and aquatic eco-systems. Not only seas but also small water bodies and watercourses, as well as coastal areas, soil and groundwater are contaminated with oil products. Contamination results in destruction of some plants or animals, but in events of high oil contamination also of the entire ecosystem. Latvia has inherited the oil pollution from both the Soviet Union large-scale industry and its military facilities, as well as at present the oil products are getting into environment from petrol stations, accidents, and from the cross-border pollution. In many cases of oil spills, people are trying to collect them in order to have no impact on the environment, but unfortunately very often, even in most cases this does not occur. Financial resources, as well as the lack of appropriate technologies or restricted possibilities for their application are the limiting factors. The article deals with the traditional methods of oil collection in water and also describes options for decontamination of polluted soil from the oil products. A brief insight is provided into application of ferromagnetic sorbents, which is a new method for collection of oil and oil products.
\end{abstract}

Keywords: ferromagnetism, oil spills, pollution.

\section{Introduction}

The biggest cause of environmental pollution today is just the oil and oil products. Most oil pollution in the World Ocean originates from the tank-ship accidents, for example, from the tank ship Erika (1999) [1], from oil pumping in ports or from the oil production platforms, as well as from accidents associated with the oil production platforms themselves. This results in a tremendous amount of oil and oil products getting into the water. It is estimated that this level amounts to 25-30 million tons of petroleum products. This group of pollution is mainly associated with the accidents, which are not always predictable and the amounts of pollution can not always be identified. Ship ballast waters are other very important polluters of the water environment. These are deliberately discharged into the seas and oceans when contaminated with petroleum products, as well as other highly hazardous substances and compounds. In any case, aquatic ecosystems are suffering, which results in perishing birds, fish, mammals and other representatives of marine flora and fauna. [2] In addition, a large proportion of all the perished organisms are concentrated exactly in the coastal area, where oil products are washed ashore, which interferes with access to oxygen in water.

Oil pollution can be reduced through additional safety measures in course of the extraction from entrails of the Earth, by using other resources, which would be less harmful and prevent leakage of industrial raw materials and products into the waters, by collecting and purification of rainwater runoff from roads and grounds. Although the human race is striving to limit oil spills, these still happen and then fast and efficient oil collecting techniques should be used, as well as new ones should be developed. 
Purification of the contaminated areas from oil can be divided in three types:

1) water purification from oil products,

2) purification of coastal areas from oil products

3) purification of contaminated ground from oil products.

Practically in all the producing enterprises their process of operations results in formation of the waste containing oil products. Substantial risk of pollution is present in comparatively small facilities, such as petrol stations, car washes, which represent a potential small-scale pollution, and in large facilities, which create or have potential to create very large amounts of oil-containing waste, such as oil handling terminals.

The main facilities creating pollution with oil products in Latvia are:

1. Former Soviet military bases,

2. Former industrial sites, where groundwater pollution has been developed from the oil products,

3. Consequences of accidents resulted in contaminated soil,

4. Petrol stations and car services,

5. Enterprises engaged in oil production, processing, handling or using oil products (lubricants, fuel, oil) in their operations,

6. Polluted soil and water bodies of the areas adjacent to railway and motor roads.

One petrol station produces from 0.5 to $2.5 \mathrm{~m}^{3}$ as the total annual amount of pollution by oil products getting into the environment. Taking into account a sufficiently large number of petrol stations across the territory of Latvia, the annual pollution volume amounts to approximately $500 \mathrm{~m}^{3}$. There is a reason to believe that the majority of pollution created by petrol stations is not accurately accounted for, collected and processed properly. [3] Also in the Latvian inland waters (rivers, lakes) oil product (mostly diesel or petrol) spills are pretty often taking place, but as a rule they are minor ones and being operatively eliminated. At the service of State Fire and Rescue Service are booms of the delimiting type (in rivers), and absorbent booms (in lakes), as well as airtight containers (for collection of contaminated soil), which can be duly delivered to any place in Latvia, for the purpose of delimiting further pollution of waters as soon as possible, and to eliminate the existing pollution with oil products. However, the oil products from motor roads and grounds are getting into the water, which is also a global problem currently being difficult to tackle.

One of the most threatening situations in Latvia during the recent years was when in the spring of 2007 unknown quantity of diesel fuel has made stream into Latvia along the flow of the Daugava River from Belarus, which threatened to develop into an ecological disaster. The diesel pollution flown into the Daugava has proved to be a number of times greater than Belarus has previously brought to notice of Latvia, which was the greatest cause for concern. The Baltic Sea is shallow, but its bed is very uneven, with sharp rises and falls, large depths and shallow places. Pollution has a strong negative impact exactly on shallow water bodies, because there are specific ecosystems that are rapidly affected by changing external factors and, in particular, such as pollution with oil products.

Technologies for treatment of the contaminated soil and associated groundwater in Latvia, taking into account the Latvian possibilities, are divided into two main groups:

1. Soil purification on the spot (in situ) in the contamination area (in fully or in partially localized area),

2. Soil purification in facilities, which can be located as a temporary purification plants in sites of the contaminated areas or located outside the said (ex situ), which require excavation of the contaminated soil.

This article analyzes the current methods and technical solutions to eliminate pollution with oil products applied on the global scale, evaluates efficiency of these methods. 


\section{Elimination of consequences of the oil product spills in the water}

Mechanical collection of oil products, first by localising them is preferred in the elimination of consequences of the oil spills. The most common manner for localization of the spilled oil is containment for holding the movement of contamination with the booms (see Figure 1) and then by its collection with mechanical devices. At present application of booms is the most commonly used oil collecting method in the world, which has both its advantages and its disadvantages.

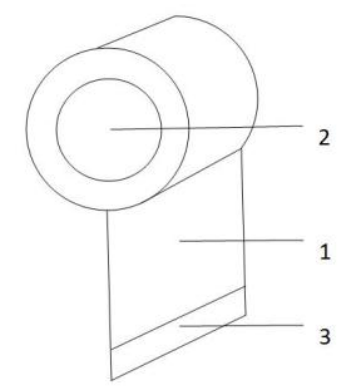

\section{Fig. 1. Cross-section of a boom}

1 - plastic material performing the oil retention function; 2 - floating material, which is capable for holding of the boom at surface; 3 - sinking material performing the plastic material (1) tension function, does not allow it to spin

Fence-type booms (see Figure 2.) is the most common variety, widely used in rivers to keep the oil products from spreading further downstream, by collecting it from running water to one place, in order to further collect the contamination by use of other technologies. They are relatively inexpensive and easy to install.

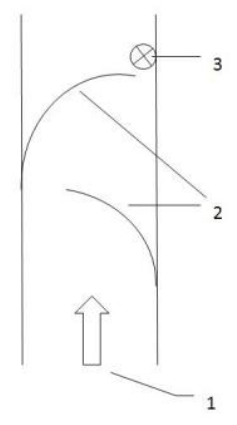

Fig. 2. Fundamental scheme of operation of the fence-type booms

1 - river stream flow direction; 2 - fence-type booms; 3 - mechanical oil collecting equipment

Spring-loaded type booms has the same function as fence-type booms, but they are easier to install, because as can be inferred from the title, their construction contains springs adjusting to the desired width of the delimitation. Springs are embedded in a buoyant material. Feature of the coastal booms is that this kind of booms is strengthened on the bank with anchors and is intended for continued operation.

Booms for detention of burning oil and chemical products are different from other types of booms in their incombustible and chemicals-resistant material used in the construction of booms.

Adsorbent booms differ from other types of booms in that the booms are filled with adsorptive material that adsorbs oil products and after multiple usage of these booms there is no need to collect it mechanically. Adsorbent booms are mounted one behind the other in running water, and each row of booms absorbs the oil products until the water runs clear. 


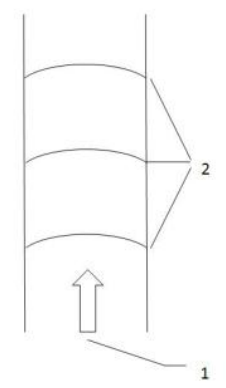

Fig. 3. Principal scheme for operation of the adsorbent booms

1 - river stream flow direction; 2 - adsorbent booms

Mutual comparison between the types of booms (see Table 1) presents evident that each of them has both their positive and negative features. For example, the booms containing oil products only ensures their moving to a certain place where the collecting of contamination is going to take place. Consequently, efficiency of the boom performance is highly dependent on the water level undulation, wind strength and direction, the river width and other factors.

Table 1.

Comparison of booms according to type of their use and characteristics

\begin{tabular}{|l|l|l|l|}
\hline \multicolumn{1}{|c|}{ Type of booms } & $\begin{array}{l}\text { Positive characteristics } \\
\text { of the booms }\end{array}$ & $\begin{array}{l}\text { Negative characteristics } \\
\text { of the booms }\end{array}$ & $\begin{array}{c}\text { Application of } \\
\text { booms }\end{array}$ \\
\hline $\begin{array}{l}\text { Fence-type } \\
\text { booms }\end{array}$ & $\begin{array}{l}\text { Of simple structure, the } \\
\text { least expensive from all } \\
\text { the types of booms }\end{array}$ & $\begin{array}{l}\text { Do not perform any } \\
\text { additional functions }\end{array}$ & $\begin{array}{l}\text { The most widely } \\
\text { used type of booms } \\
\text { for localization of } \\
\text { the oil products }\end{array}$ \\
\hline $\begin{array}{l}\text { Spring-type } \\
\text { booms }\end{array}$ & $\begin{array}{l}\text { Quickly installable, } \\
\text { quickly removable, } \\
\text { occupies small space in } \\
\text { a,rest state” }\end{array}$ & $\begin{array}{l}\text { Do not perform any } \\
\text { additional functions }\end{array}$ & $\begin{array}{l}\text { Used for the } \\
\text { purpose to localize } \\
\text { spills as fast as } \\
\text { possible, rare type } \\
\text { of booms }\end{array}$ \\
\hline Coastal booms & $\begin{array}{l}\text { May be left for longer } \\
\text { time due to the coast } \\
\text { anchors }\end{array}$ & $\begin{array}{l}\text { Do not perform any } \\
\text { additional functions }\end{array}$ & $\begin{array}{l}\text { Used in places } \\
\text { where the pollution } \\
\text { will arrive after } \\
\text { undetermined time }\end{array}$ \\
\hline $\begin{array}{l}\text { Booms for } \\
\text { containment of } \\
\text { burning oil and } \\
\text { chemical } \\
\text { products }\end{array}$ & $\begin{array}{l}\text { Incombustible material } \\
\text { contains burning oil } \\
\text { helping to extinguish } \\
\text { the same }\end{array}$ & No & $\begin{array}{l}\text { Are used in the oil } \\
\text { extraction sites, } \\
\text { most often after } \\
\text { accidents, when } \\
\text { burning oil is } \\
\text { extinguished }\end{array}$ \\
\hline $\begin{array}{l}\text { Adsorbent } \\
\text { booms }\end{array}$ & $\begin{array}{l}\text { After multiple rows of } \\
\text { adsorbent booms, } \\
\text { mechanical collecting } \\
\text { of pollution is not } \\
\text { required }\end{array}$ & No & $\begin{array}{l}\text { Used in rivers with } \\
\text { small stream flow, } \\
\text { used in multiple } \\
\text { rows }\end{array}$ \\
\hline
\end{tabular}

In Latvia collecting and delimitation of pollution with oil products in the water bodies is carried out by the Latvian Naval Forces having several types of booms at their disposal. They have several types of containment booms at their disposal, which are characterized by their length, depth of the draught, the principle of installation and speed. For example, the marine boom RO-BOOM 1500 is $600 \mathrm{~m}$ long, boom draught $700 \mathrm{~cm}$, these booms are spooled, pull- 
driven with mechanical gear. Coil weight together with booms constitutes $4000 \mathrm{~kg}$. These booms are intended for use in elimination of accidents on sea, the Ventspils naval forces are equipped with them. In Latvia light, fast-installable booms HV-2040 SC are also used, intended for inland waters with the wave height of less than $30 \mathrm{~cm}$, booms are spooled. Coil weight together with booms is $880 \mathrm{~kg}$, length - $220 \mathrm{~m}$. The Latvian Naval Forces are equipped also with the adsorbent booms. Like the containment booms they vary in length, but this type of booms are mounted one after the other, therefore, to use adsorptive surface of the booms more effectively, the boom length can be varied, by constructing the required length from the package rolls and the remaining rolls to be used for re-adsorption. The length of adsorbent boom ranges from 200 to $3000 \mathrm{~m}$.

One of the latest methods for collecting of oil products is the use of ferromagnetic sorbents. In order to combat pollution with oil products, physical properties of the spilled oil film have to be changed, to invest it with magnetic properties. To achieve this water is supplied with a specially designed ferromagnetic adsorbent based on an iron powder produced by processing of the metal industry waste. $[4,5]$ Experimental method tested in laboratory conditions enables modification of physical properties of the surface oil film by adding ferromagnetic sorbent. Powder "Fe-S1" is sprayed on the oil spot (see Figure 4) by using spray devices, and after 5-10 min. ferromagnetic powder absorbs them, forming the surface with a powerful magnetism.

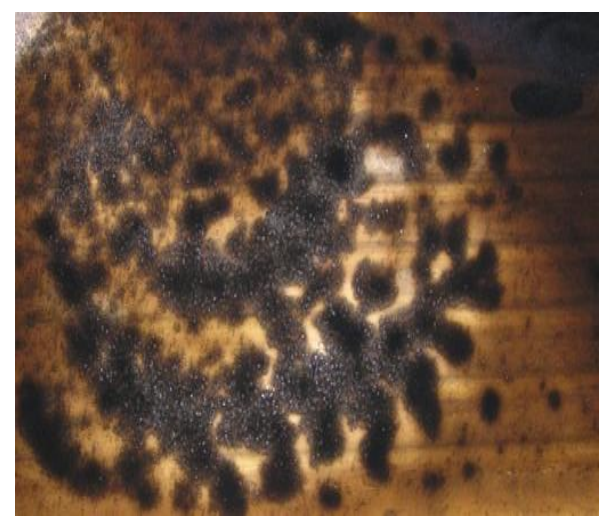

Fig. 4. Water surface after reaction with the ferromagnetic adsorbent

Due to magnetic interaction the suspension turns into balls, vacating large water area $(80 \%)$ from oil. The resulting suspension can be effectively collected using a specially developed magnetic catcher. [6]

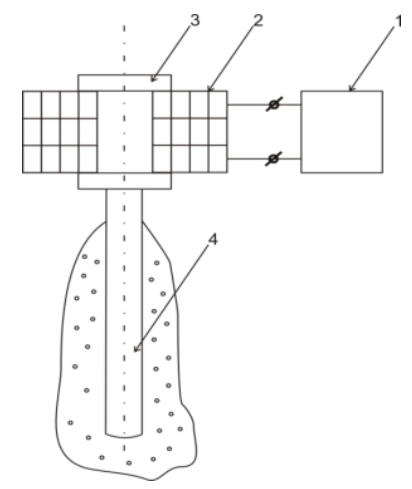

Fig. 5. Apparatus for collecting spilled oil products

1 - power source; 2 - electromagnetic coil; 3 - core; 4 - catcher 
Principal scheme of apparatus for collection of the spilled oil products is provided in Figure 5. At development of this sorption method to a commercially viable one, additional research must be conducted, as well as possible combinations have to be created with other sorbents, to increase buoyancy and efficiency of the sorbent. The method has the advantage that by the same it is possible to assemble also the sunken waste of oil products that previously has reacted with the adsorbent.

\section{Purification of contaminated ground}

Pollution with oil products or their components should be considered as one of the most significant forms of soil and groundwater contamination. Currently, such pollution is found in virtually all the major enterprises for transport, handling and storage of oil products. Due to several reasons, mainly historically and for Latvia as a transit country, large amount of this hazardous waste has developed, which poses a serious threat to the development of a number of Latvian territories because of contamination, including by creation of groundwater pollution risks as well as by overall negative impact on the environment.

Under influence of this contamination, adverse environmental impact on adjacent areas is taking place, mainly in the groundwater flow direction. To improve the situation in the urban industrial zone, the environmental restoration activities are enforced mainly aimed at gradual elimination of the soil and groundwater contamination and of the causes for its formation. Ground contamination may be result of failures in diesel, heavy fuel oil and thermoils' pipelines in the event of oil spill without ignition. In event of such an accident, depending on its degree (from small leakages to complete pipe failure) and type of the spilled oil product, also the extent of soil pollution is evaluated, which can take up even very large areas. Removal of pollution of the contaminated soil is carried out using physical or chemical means.

Sieve or physical separation. The separation process uses sieves and screens of different sizes for effective concentration of oil and oil products in smaller quantities. Physical separation is based on the fact that organic and inorganic matters combine with each other both chemically and physically, especially becoming apparent in clay and mud. Clay and mud particles are physically attached to the coarse sand or soil, perfectly concentrating the oil products in a small unit volume, so it is easier to handle. Physical separation is usually carried out prior to chemical treatment, provided that the majority of oil products remain with large-scale soil particles. The major advantage of physical separation is that high level of purification can be achieved with a relatively small amount of devices. However, there are many factors that can limit effectiveness and usability of both these processes. One of such is the high content of clay and moisture in the soil, which increases purification costs.

Removal of oil products with the help of gravitational force. The process is based on a difference of densities between the solution phases. Equipment size and removal efficiency with the gravitational force is dependent on the size of particles of oil or its products, density difference, viscosity and concentration of particles. Separation by gravitation is used also to remove unmixable oil layers, and to classify the particles with different sizes. Usually it is preceded by coagulation and flotation to increase the size of particles, which facilitates the separation process.

Biodegradation. This technology can be used in large quantities. Soil is mixed with soil improvers and subjected to further treatment. For example to soil ventilation. It is used to reduce concentration of oil products in the soil resulting from biological decomposition. Humidity, high temperature, nutrients, oxygen and $\mathrm{pH}$ are the main parameters of biological decomposition, which, of course, micro-organisms. The soil is placed in a limited field where soil piles are formed. Most often the soil piles (maximum 2 - $3 \mathrm{~m}$ high) are covered by a film to maintain moisture and heat under the film. Biodegradation is aimed at modification or destruction of oil and stimulation of micro-organisms in order for the latter consume the oil as 
a source of nutrients and energy. Certain groups of oil products do not decompose completely, but their degradation products become even more toxic, and they have other by-products, decomposition of which is difficult (such as vinyl chloride). Biodegradation is a relatively short-term technology, although the process can last for weeks and even months. The biggest advantage is low cost. However, disadvantages include relatively high costs associated with excavation and transportation of contaminated land.

Soil rinsing. Oil products are sorbed on the ground particles. During the ground rinsing process (see Fig. 6) water is saturated with leaching agents, surface active substances, $\mathrm{pH}$ regulating substances or coagulants that help to separate the organic matter. In the soil leaching process oil products are separated in two ways:

1. by releasing or creating other substances,

2. by exercising concentration of oil products.

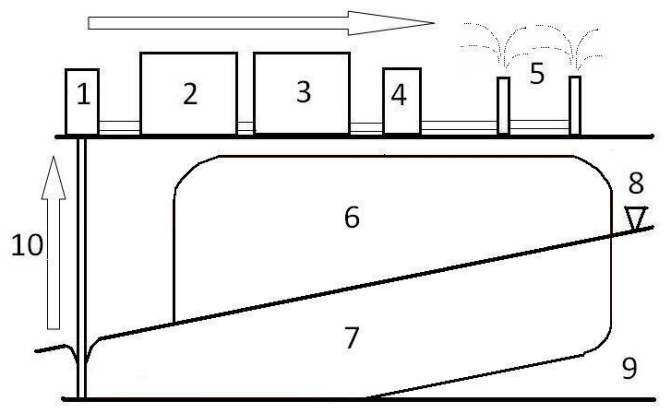

Fig. 6. Rinsing of soil contaminated with oil products

1 - pump; 2 - groundwater treatment; 3 - rinsing additives; 4 - pump; 5 - spraying equipment; 6 - contaminated area; 7 - contamination diffusion with groundwaters; 8 - groundwater level; 9 - unpolluted ground; 10 - water circulation direction

Concept of purification of the contaminated soil by reducing the particles is based on the fact that oil and oil products tend to be connected physically or chemically with the clay, mud or organic soil particles. While the clay and mud is attached to the sand by physical methods, such as compaction and adhesion. During the washing process not only clay and sand is separated from the ground, but the oil particles in ground are also reduced in order to make work with them easier. Also for this method there are a number of factors that may limit the effectiveness and usability of the process. Washing the ground, which is contaminated by oil products can result in emergence of many and various unnecessary solutions (e.g., organic matters, heavy metals) requiring additional treatment thus increasing the costs and complicating the purification process. High content of humus in the soil can lead to high costs, because in clayey soils separation of the humus substances is difficult.

Hot gas dezactivation. During the heating process, the material or the substance is heated to temperatures where gaseous oil compounds are emitted, which are burnt in special incinerator. The disadvantage is that eventual explosivity and ignition speed of the substance should be foreseen, as well as the costs of this method are much higher than for incineration on the open flame.

Incineration. Mobile equipment is used for evaporization, and incineration of oil and oil products at a temperature of $870-1200{ }^{\circ} \mathrm{C}$. Fuel is often used to assist in starting and ensuring of complete incineration. The method is used in particularly heavily polluted grounds (above $5000 \mathrm{mg} / \mathrm{kg}$ ) for utilization in the areas due to long distances of geographical location not allowing for cost effective transportation of the contaminated ground to stationary treatment plants. The method is one of the most efficient when compared to others in cases where the volumes of polluted ground are not too large (up to 100 tons), it is situated locally, area is 
placed at a long distance, and the ground can not be utilized via other processing technologies. Incineration achieves $99.99 \%$ efficiency. According to qualitative criteria the method is one of the cleanest and the fastest, but at the same time the most expensive of methods for utilization of the ground polluted with oil products. Rotary kilns are widespread installations of this method.

Pyrolysis converts oil pollution to gaseous components, liquid and coke. In course of pyrolysis the oil products emit hot gases, including carbon monoxide, hydrogen and methane, as well as other compounds. Pyrolysis takes place at low pressure and temperatures above 430 ${ }^{0} \mathrm{C}$. Gases emitted during pyrolysis are requiring further processing. This is done in the second chamber, where gases can be burned to allow them to ignite and to be recycled. Disadvantage of the technology is that it requires soil drying in order to achieve low soil moisture $(<1 \%)$, which also increases the total cost of treatment.

Stabilization. This method is used to stabilize the oil and its compounds, and they do not spread further into environment. In cementing and stabilization technologies, processes are directed towards the sealing or stabilization of oil products, as well as including treatment of excess or contaminated ground. There are 4 groups, which may be involved in the cementing process of oil and its products:

1. bitumenization,

2. asphalt emulsion,

3. modified cement sulfur,

4. glass vitrification.

Under the bitumenization process the contaminated area is placed in liquid asphalt and it is hardened. The process combines heated asphalt and concentrated unnecessary material in a form of sludge. From the mixture water evaporates to about 5\% level. The final product constitutes homogenized mixture of oil products and asphalt.

Asphalt emulsion is made of small asphalt droplets placed in the water, and being stabilized by chemical emulsion agents. There are cationic and anionic emulsions. Asphalt emulsion process is taking place in hydrophilic solvents where asphalt emulsion is mixed with oil products. After mixing the excess water is drained and the asphalt emulsion membrane covers remains of the oil products. Additional neutralizing agents, such as gypsum or lime are sometimes required. After hardening even the water can not access the oil mass incorporated in the hard mass.

The modified cement sulfur commercially is one of the most available thermoplastic materials. It is easy to melt, then mixed with oil products to form a homogeneous liquid solution, which is placed in special containers for freezing or chilling, and for subsequent use. Vitrification or glass casting - solidification methods, which is heated up to $1.200 \mathrm{EC}$, to melt and to transform unnecessary materials in glass or other vitreous products. The high temperature destroys any organic elements with a few by-products. Materials such as heavy metals and petroleum products turns resistant to rinsing by incorporation into a glass structure that is rigid and durable material. To solid material also liquids, dry or wet waste, as well as combustible materials can be added. Borosilicate and soda lime are the main constituting elements of the vitrification matrix. However, in relation to oil and its products, the stabilization process has one major disadvantage - all organic materials, including, of course, oil and oil products are difficult to stabilize, and this stabilization can not be enduring.

Integrated pumping out of pollutants and water. Unlike pumping out the emulsion of oil products and water, in this case boring holes are created below the groundwater level. The method is used both in event of diffuse and local groundwater pollution. Within the pollution area boring holes are created and pumping out of the borehole water is ensured. Similar to the previous method, development of a cone of depression is achieved, where pollutants and contaminated groundwater is moving. Further through pumps the pollution and water emulsion is collected in tanks and transported to the stationary treatment plants. 
Pumping out of emulsion of oil products and water is done by means of making boring holes within the pollution area above the groundwater layer and by pumping out developing a cone of depression. As a result, pollution of the floating layer of groundwater is pumped out and removed. Further the oil and water mixtures collected in reservoirs should be transported to the stationary treatment plants.

\section{Conclusions}

In elimination of consequences from the oil spills, priority is given to mechanical collecting of the oil products, first by localizing them with booms. The most widespread types of booms are containment booms and adsorbent booms. Adsorbent booms have the advantage that after their use the collecting of oil products with mechanical devices is not required, but as the negative feature of these booms may be pointed out that in the adsorbent booms adsorption material has to be replaced and the booms can be used only once.

Currently the purification of ground contaminated with oil products is based on methods such as soil rinsing, thermal treatment, biodegradation and so on. Methods are widely applied, but are expensive. Consequently, for the time being in Latvia there are lots of sites contaminated with oil products, where their owners can not afford to clean up the polluted ground.

Use of ferromagnetic adsorbents is a new method for collecting of oil products, which has not yet been explored to the commercial product. Research studies are ongoing, but the results are evident that this could be one of the ways to clean up the surface from the oil pollution without degrading the environment.

\section{Acknowledgements}

This article has been partly co-financed by the project "Environmental Technology Transfer: Rezekne Higher Education Institution - Business Companies" No. TPK/2.1.2.1.2/08/01/010, agreement on the implementation of the project No. L-TPK-08-0006.

\section{Bibliography}

1. Ernst, S.R., Morvan, J., Geslin, E., Le Bihan, A., Jorissen, F.J., 2006. Benthic foraminiferal response to experimentally induced Erika oil pollution. Marine Micropaleontology 61, 76-93.

2. Camphuysen, C.J., Heubeck, M., 2001. Marine oil pollution and beached bird surveys: the development of a sensitive monitoring instrument. Environmental Pollution 112, 443-461.

3. Blumberga, A., Blumberga, D., Kl̦aviņš, M., Rošā, M., Valtere, S., 2010. Vides tehnolog̣ijas. Rīga: LU, 212 lpp.

4. „Processing of Powder Materials by Pulse Electromagnetic Field”, Viktors Mironovs, 2010.

5. LV Patent 13927B Sorbent for collection of oil products, Mironovs, V., Lapkovskis, V., Zemčenkovs, V.

6. LV patent 13911B 2009/08/20, Int. Cl E02B15/04. V. Mironovs, V. Belova, V. Zemčenkovs. Apparatus for collection of spilled oil products. LR patents, RTU. 